\title{
A partial systematic revision of the day geckos, Phelsuma Gray, of Madagascar (Reptilia: Squamata: Gekkonidae)
}

\author{
CHRISTOPHER J. RAXWORTHY AND RONALD A. NUSSBAUM \\ Division of Herpetology, Museum of Zoology, University of Michigan, Ann Arbor, \\ Michigan 48109, U.S.A.
}

\begin{abstract}
Recent survey work in Madagascar has led to significant changes in the systematics of Madagascan Phelsuma. A new species from the Masoala Peninsula in northeastern Madagascar is described, which has a nostril position typical of Phelsuma from Mauritius, Reunion and Rodriguez islands. Phelsuma breviceps was rediscovered in extreme southern Madagascar and is resurrected from the synonymy of $P$. mutabilis. Phelsuma breviceps has fragile skin, a probable predator escape mechanism, similar to the condition found in geckos of the genera Ailuronyx and Geckolepis. Three new synonyms are recognized. Phelsuma befotakensis and $P$. checki are junior synonyms of $P$. abbotti, and $P$. minuthi is a junior synonym of $P$. lineata. Twenty species of Phelsuma occur in Madagascar, of which 16 are endemic. A checklist and identification key are provided. Conservation problems of Phelsuma in the coastal regions of Madagascar are briefly discussed.
\end{abstract}

ADDITIONAL KEY WORDS:- taxonomy - lizards - Africa - conservation.

\section{CONTENTS}

\begin{tabular}{|c|c|c|c|c|c|c|c|c|}
\hline Introduction & & & & & & & & 321 \\
\hline Material and methods & . & . & . & . & . & & & 322 \\
\hline New synonyms & & . & . & . & . & & & 322 \\
\hline Resurrection of Phelsuma & breviceps & & . & . & . & & & 324 \\
\hline Descriptions & & & . & . & . & r. & & 325 \\
\hline Phelsuma breviceps $\mathrm{Bo}$ & pettger & & . & - & . & . & & 325 \\
\hline Phelsuma masol & hoala sp & p. n & ov. & . & . & . & & 328 \\
\hline Checklist of Phelsuma fro & m Mada & agasc & & & . & . & & 331 \\
\hline Identification key to the & Phelsuma & & Mad & agasc & & . & & 331 \\
\hline Discussion . & . & . & . & . & . & . & - & 33 \\
\hline Acknowledgements & . & . & . & . & . & . & & 334 \\
\hline References . & . & . & . & . & . & . & . & 335 \\
\hline
\end{tabular}

\section{INTRODUCTION}

The day geckos of the genus Phelsuma Gray 1825 occur throughout the Indian Ocean region. Until now the genus included 34 species (Kluge, 1991; Seipp, 1991; Raxworthy \& Nussbaum, 1993), the majority of which occur in Madagascar. Phelsuma is the most speciose gekkonid genus in Madagascar, occurring in all the major native forest habitats and showing a high degree of 
local endemicity. Prior to this study, 21 Phelsuma species were known from the island, of which 16 were endemic.

In 1993 we collected two unusual species of Phelsuma. One from northeastern Madagascar is undescribed, and the other from southern Madagascar had been considered a junior synonym of Phelsuma mutabilis (Grandidier, 1869). Comparative studies of the other species of Malagasy Phelsuma led us to recognize three new synonyms which we discuss in this paper. Because of the recent description of several new Malagasy species, recognition of new synonyms, and the resurrection of a previously synonymized species, we present an updated checklist and a new identification key for the Phelsuma of Madagascar.

\section{MATERIAL AND METHODS}

Specimens were captured by hand during the day or night. Representative live specimens were photographed to record colour. Specimens were fixed in $10 \%$ buffered formalin and stored in 75\% alcohol. All measurements were taken from preserved material using a ruler to the nearest millimetre, or to the nearest $0.1 \mathrm{~mm}$ using a graticule and binocular microscope. Snout-vent length is abbreviated to SVL; 'UMMZ' refers to the University of Michigan, Museum of Zoology.

\section{NEW SYNONYMS}

Phelsuma befotakensis and P. chekei.

Börner \& Minuth (1982) described two species of Phelsuma collected in northern Madagascar: P. befotakensis from Befotaka and $P$. chekei from Antsiranana (Diégo Suarez). Two years later, Börner \& Minuth (1984) again published almost identical descriptions of both species, perhaps because the original descriptions were in an almost unknown journal edited, published, and distributed by the senior author. The holotype (BSRG Geck $36 \mathrm{MG}$ ) and paratypes (BSRC Geck $20 \mathrm{MG}$ and BSRC Geck $33 \mathrm{MC}$ [not BSRC $33 \mathrm{SG}$ as given by Börner \& Minuth, 1982]) of Phelsuma checki, and the holotype (BSRC Geck 82 SC) and paratypes (BSRC Geck 80-81 SC) of P. befotakensis were reported to be in the junior author's private collection (Börner \& Minuth, 1984).

In the original description (Börner \& Minuth, 1982), the diagnoses of both new species are given without reference to other species, except that the body form of $P$. chekei was considered 'comparable to the forms of Menai and Mahé on the one hand and to the even stouter form of Assumption'. The species of these 'forms' was not stated, although in their second description Börner \& Minuth (1984) admitted that all previous authors included both $P$. checki, and $P$. befotakensis under the name $P$. abbotti Stejneger 1893.

Phelsuma befotakensis and $P$. chekei are obviously very similar to each other. Phelsuma befotakensis was described as having adhesive pads on the tocs that are not as wide as those of $P$. chekei, although no measurements were provided to support this statement. In all the scalation characters the two species overlap, except for the number of scales around midbody $(68-72$ P. befotakensis, 74-78 $P$. chekei). One character was claimed to be unique to $P$. chekei: the widelyspaced dorsal and lateral scales of the body. 
Cheke (1981) examined specimens of Phelsuma abbotti from Cosmoledo, Assumption, Aldabra and Madagascar. He considered $P$. abbotti abbotti to be restricted to Aldabra, $P$. abbotti sumptio Check, 1981, to be restricted to Assumption Island, and transferred the Cosmoledo specimens from $P$. abbotti to $P$. longinsulae menaiensis Mertens, 1966. The Madagascan $P$. abbotti are similar to specimens from Aldabra and Assumption but tend to be 'strongly bluish in color, with coarser markings' (Cheke, 1981: 191). Cheke described Madagascan $P$. abbotti as dorsally dull green to dull blue on the body and head, with black or reddish-brown markings, a white or yellow venter, and a broad head; and the Aldabran $P$. abbotti as dorsally dull green with black and reddish-brown markings on the head and body, a white venter, and a narrower head.

We examined $P$. abbotti abbotti material from the type locality, Aldabra Island (UMMZ 188396-8, 188412-4, 189404) and UMMZ P. abbotti from Antsiranana (Diégo Suarez) (201451), Montagne de Francais (203673-4), Ambilobe (203672), and Ankarana (201452-5, 203675-8), all in northern Madagascar. The widely spaced dorsal and lateral scales of the body, claimed to be unique to $P$. chekei, are present in all the $P$. abbotti material, including Aldabra. The intensity of body markings (vertebral line and laterally spotting) is variable within both the Aldabra and Madagascar populations, varying from very faint to bold. Colour photographs of the Madagascar specimens show these markings are dull reddishbrown or dark grey in life. Dorsally the head and body coloration is pale grey, pale blue or pale green. The relative head width (maximum head width/SVL) for of the Aldabran and Madagascan specimens (SVL 46-57 mm) is very similar: Aldabran, 0.19-0.23, mean $=0.208, \quad n=5$; Madagascan $0.18-0.21$, mean $=0.202, n=12$.

We are unable to find convincing characters that separate $P$. befotakensis from $P$. chekei. We are also unable to find significant differences between Aldabran $P$. abbotti and either $P$. befotakensis or $P$. chekei. Therefore, we consider both $P$. befotakensis and $P$. chekei to be junior synonyms of $P$. abbotti.

\section{Phelsuma minuthi}

This species was described by Börner (1980) based on a single specimen that had died in captivity. The geographic origin of the holotype is not known, probably because it was originally supplied by the pet trade, although this is not actually stated by Börner. The depository for the holotype (BSRG Geck $19 \mathrm{MC}$ ) is not given, but it is probably a private collection.

Börner (1980) recognized $P$. minuthi as belonging to the lineata group, and considered it most similar to $P$. lineata Gray, 1842. He compared $P$. minuthi to seven $P$. lineata specimens and diagnosed $P$. minuthi by the presence of a tiny distal spine on each dorsolateral and lateral tail scale, 12 scansors under the 4th toe, and 9 scansors under 4th finger. Börner did not describe the condition of the tail for the seven $P$. lineata specimens, but he gave a scansor range of 15-17 for the 4th toe and 12-16 for the 4th finger. Phelsuma lineata has keeled ventral scales, an obvious black lateral line on the body, and non-serrated tail whorls, all of which are also present in $P$. minuthi. Geographic variation is prominent in $P$. lineata, a species that occurs throughout much of Madagascar, with six currently recognized subspecies.

We compared UMMZ specimens of $P$. lineata collected by us to the description of P. minuthi. Phelsuma lineata from Marovony $(196815,196821)$ and Manombo 
(196831), both in the southeast, and Manongarivo (201554, 201556, 201558-9, 201561-2), in the northeast, had scansor counts similar to $P$. minuthi (which has 12 and 9 scansors for the 4th toe and finger respectively). The scansor counts for the 4th toe are: 11 (201554), 12 (201556, 201558-9, 201561), 13 $(196815,196821,196831,201562)$. The scansor counts for the 4 th finger are slightly higher than P. minuthi: 10 (201560), 11 (201554, 201559, 201562), 12 (196815, 196821, 196831, 201556, 201558, 201561). Within this $P$. lineata series, some specimens have the same number of toe scansors as $P$. minuthi, while there is a difference of just one scansor between the $P$. minuthi holotype and P. lineata 201560.

The other diagnostic character of $P$. minuthi is the tiny spine positioned distally on each scale of the dorsolateral and lateral surfaces of the tail. All $P$. lineata have strong keeling on the lateral and dorsolateral tail scales, and the keel may form a point at the posterior edge of some scales. The holotype of Phelsuma minuthi may have unusually strong keeling on the tail scales, which would give the appearance of spines.

The similar numbers of scansors of $P$. minuthi and $P$. lineata, and the probable confusion between tail keeling and tail spines, indicate that the two forms are not distinct; and we consider $P$. minuthi to be a junior synonym of $P$. lineata.

\section{RESURRECTION OF PHELSUMA BREVICEPS}

Phelsuma mutabilis was described by Grandidier in 1869 based on material from Fierin and Menabe, in western Madagascar. In 1894, Boettger described $P$. breviceps, a species he compared to $P$. madagascariensis and $P$. laticauda, but not to $P$. mutabilis. The single male $P$. breviceps available to Boettger was collected at the southern tip of Madagascar.

In 1901 Mocquard described $P$. androyensis from Androy in southern Madagascar. Just a year later he recognized $P$. androyensis as a junior synonym of $P$. mutabilis, and provided a detailed new description of the latter species (Mocquard, 1902). Mocquard (1901) clearly recognized the similarities of $P$. mutabilis and $P$. breviceps, and he provided a detailed diagnosis to separate the two species. Phelsuma breviceps was distinguished from $P$. mutabilis by its shorter and conical (not dorsoventrally depressed) snout, two rather than one postnasals, three rather than four pairs of postmentals, small chin granules posterior to the postmentals that did not decrease gradually in size posteriorly, subcaudal scales not strongly dilated transversely, absence of five longitudinal lines on the head, and the absence of vermiculations on the body.

Boettger (1913) described another species, P. micropholis, from specimens collected from Tsimanampetso and Menabe (southern and western Madagascar). Phelsuma micropholis was subsequently recognized as a junior synonym of $P$. mutabilis by Loveridge (1942) who examined the cotypes of this species. Loveridge listed $P$. breviceps as a valid species, although in his identification key he indicated that $P$. breviceps may not be distinct from $P$. mutabilis. Mertens (1962) and Wermuth (1965) continued to recognize $P$. breviceps, but Börner (1972) considered $P$. breviceps to be subspecies of $P$. mutabilis. Blanc (1972) did not include $P$. breviceps in his Madagascar species list, and this has been followed by IUCN/UNEP/WWF. (1987). Kluge (1991) listed $P$. breviceps as a junior synonym of $P$. mutabilis. 


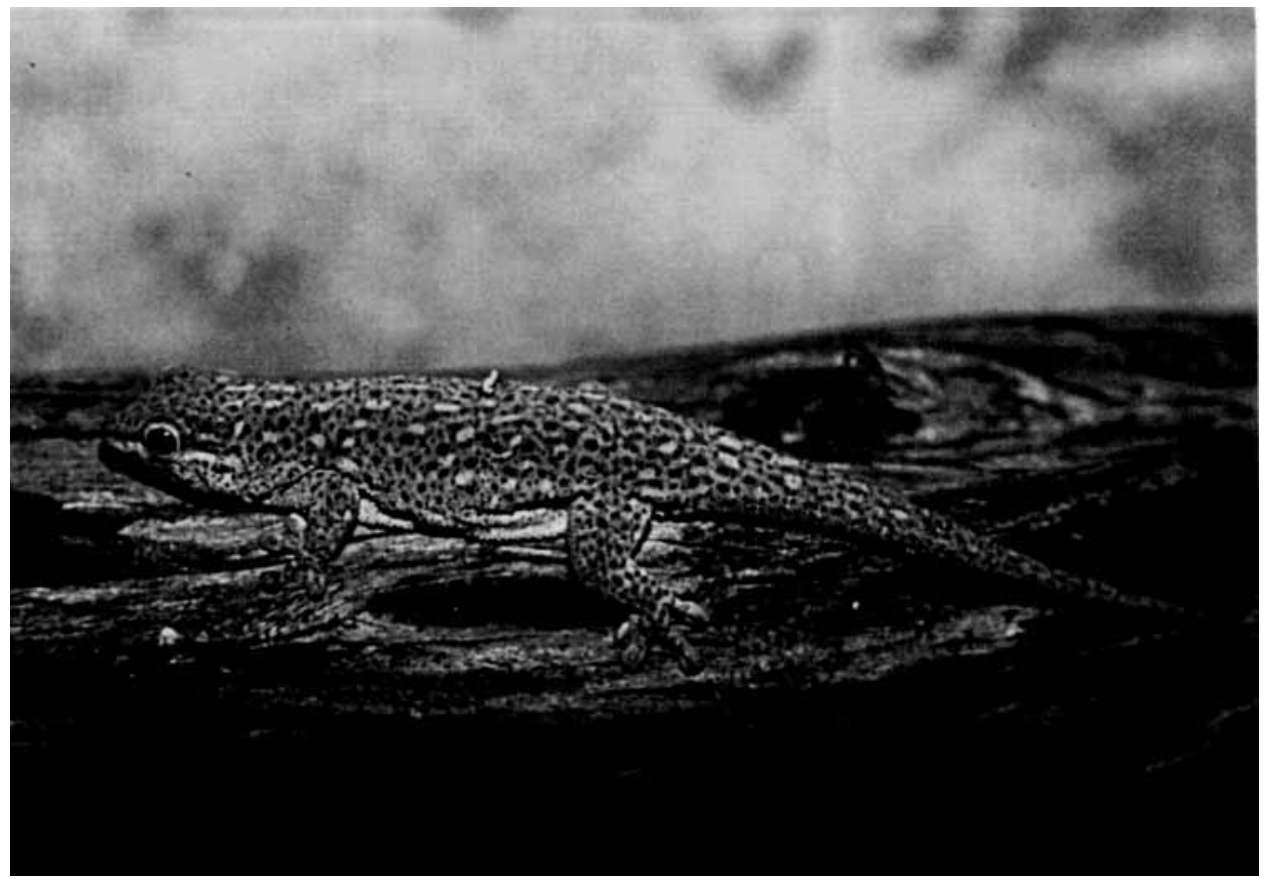

Figure 1. Phelsuma breviceps Boettger (UMMZ 203687).

We recently collected Phelsuma specimens in southern Madagascar, that clearly fit the description of $P$. breviceps and that are distinctly different from specimens of $P$. mutabilis. We conclude, therefore, that $P$. breviceps is a valid species, and provide a description and diagnosis based on our new material.

\section{DESCRIPTIONS}

\section{Phelsuma breviceps Boettger}

(Figure 1)

Type species. Phelsuma breviceps Boettger, 1894: 137. Holotype. SMF (NaturMuseum und Forschungs-Institut Senckenberg) 9465 (not seen). Male, collected by C. Brancsik.

Type locality: 'Südspitze von Madagaskar'.

\section{Material examined}

UMMZ 203679 87, collected 15 July 1993, at Betanty (Faux Cap), 25³4’S, $45^{\circ} 31^{\prime} \mathrm{E}, 60 \mathrm{~m}$ altitude, Tsiombe Fivondronana, Toliara Province, Madagascar, by Ronald. A. Nussbaum and Gabriellà Raharimanana.

\section{Diagnosis}

A medium-sized, robust Phelsuma up to $54 \mathrm{~mm} \mathrm{SVL}$; nostril placed above the first labial (posterior to the suture between the rostral and first supralabial); no median cleft on the rostral; 1-2 intersupranasal granules; subcaudal scales strongly enlarged transversely; males with 30-32 femoral pores; 27-36 dorsal 


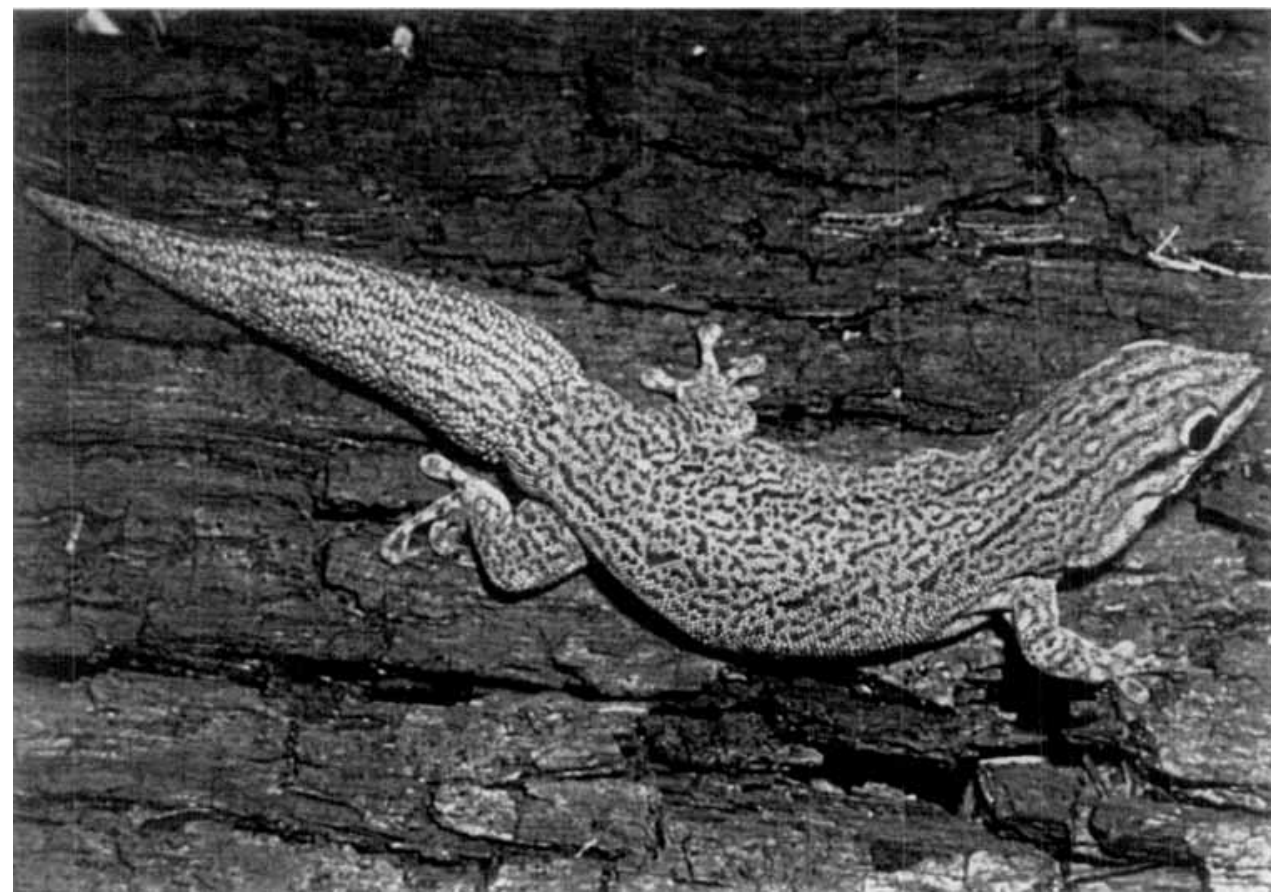

Figure 2. Phelsuma mutabilis from Zombitsy, southwestern Madagascar.

granules between anterior corners of orbits; one postnasal; chin granules posterior to the postmentals small and do not gradually decrease in size posteriorly; integument extremely fragile in life; no dark line on internal borders of infralabials and no vermiculations on dorsal body.

The most similar species, P. mutabilis, shares the following characters: nostril placed above the first labial; median cleft on the rostral may be absent; 1-3 intersupranasal granules; subcaudal scales strongly enlarged transversely; males with 27-32 femoral pores. Phelsuma mutabilis can be identified by the following characters: 18-21 dorsal granules between anterior corners of eye orbits; 1-2 postnasals; chin granules posterior to the postmentals gradually decrease in size posteriorly; integument not fragile in life; a dark line on internal borders of infralabials, and dark vermiculations on dorsal body (Figure 2).

\section{Description of UMMZ 203687}

The specimen is well fixed and undamaged, except for two transverse tears in the dorsal body integument and the detached tail, broken $6 \mathrm{~mm}$ posterior to vent. Hemipenes partially everted. Testes white, enlarged; left testes $6 \mathrm{~mm}$ long and $3 \mathrm{~mm}$ wide.

Measurements in Table 1. The nostril contacts the rostral, first supralabial, supranasal, and one postnasal; centre of nostril above first supralabial (posterior to suture between rostral and first supralabial); rostral without median suture (cleft); two intersupranasal granules; six (left) and seven (right) supralabials; six (left) and seven (right) infralabials; two large postmentals contact mental posteriorly; five distinct pairs of postmentals internal to the infralabials (on the right side the third is divided by a median suture); three slightly enlarged scales 
TABLE 1. Variation in Phelsuma breviceps. $\mathrm{M}=$ male, $\mathrm{F}=$ female; $*=$ partly regenerated; mut. $=$ mutilated.

\begin{tabular}{lccccccccc}
\hline Character & \multicolumn{10}{c}{ UMMZ number } & & \\
& 203679 & 203680 & 203681 & 203682 & 203683 & 203684 & 203685 & 203686 & 203687 \\
\hline Sex & $\mathrm{M}$ & $\mathrm{F}$ & $\mathrm{M}$ & $\mathrm{F}$ & $\mathrm{F}$ & $\mathrm{F}$ & $\mathrm{M}$ & $\mathrm{F}$ & $\mathrm{M}$ \\
SVL (mm) & 53 & 50 & 54 & 25 & 50 & 47 & 51 & 37 & 53 \\
tail length (mm) & 48 & 41 & 64 & 29 & 45 & $25^{*}$ & 51 & $26^{*}$ & $61^{*}$ \\
femoral pores & 32 & - & mut. & - & - & - & 30 & - & 32 \\
internasal granules & 1 & 1 & 1 & 2 & 1 & 1 & 1 & 1 & 2 \\
supralabials (left/right) & $7 / 7$ & $7 / 7$ & $6 / 7$ & $7 / 7$ & $7 / 6$ & $8 / 7$ & $6 / 7$ & $6 / 7$ & $6 / 7$ \\
$\begin{array}{l}\text { infralabials (left/right) } \\
\text { 4th toe scansors and median }\end{array}$ & $6 / 7$ & $? / 6$ & $6 / 6$ & $6 / 6$ & $6 / 6$ & $6 / 7$ & $6 / 6$ & $6 / 6$ & $6 / 7$ \\
$\quad$ & 21 & 20 & 21 & 21 & 20 & 20 & 20 & 20 & 20 \\
granules between ant. corner & & & & & & & & & \\
$\quad$ of orbits & 36 & mut. & 28 & 29 & 28 & 27 & 27 & 30 & 34 \\
maximum body diameter (mm) & 17 & 16 & 18 & 8 & 17 & 13 & 16 & 13 & 18 \\
axilla-groin (mm) & 22 & 24 & 25 & 11 & 23 & 21 & 23 & 17 & 24 \\
\hline
\end{tabular}

posterior to the first pair of postmentals, with the rest of chin covered in uniform small granules; snout tip to anterior margin of eye 1.5 times as long as distance between posterior margin of eye and tympanum; maximum head depth 1.3 times as long as snout tip to anterior margin of eye; 34 dorsal granules between anterior corners of orbits; smooth ventral scales on venter; smooth dorsal granules on body; $33 \mathrm{~mm}$ of tail regenerated; subcaudals enlarged transversally, up to three times wider than long on original tail; tail whorls not obvious on original or regenerated tail; tail profile smooth; forelimb with five digits, the internal (digit I) reduced in size; hindlimb with five digits, the internal (digit I) reduced in size; total number of subdigital scansors and median scales in order from digit $\mathrm{I}-\mathrm{V}$ : right manus 3-12-15-20-11, left manus 3-1115-20-12, right pes 3-11-16-20-15, left pes 3-11-16-21-15; pupil round.

The coloration in life is grey dorsally, with fine brown spots on the head, body, limbs and tail, and some slightly larger pale bluish-green spots on the body. A faint, dark brown, eye line starts at the nostril, passes through the eye above the tympanum, and fades on the neck. The labials are pale grey with small scattered brown spots. The chin and throat are white with fine pale brown spots, densest on the granules behind the postmentals. The venter and ventral surfaces of limbs and tail are white, with a few pale brown spots. The regenerated ventral surface of the tail has a faint median line of pale brown spots.

After 1 month in formalin and 1 month in alcohol, the bluish-green pigment has become grey.

\section{Variation}

The morphometric variation of the other UMMZ specimens is listed in Table 1. UMMZ 203686 has dark brown labials and dense brown spotting on the anterior region of the chin.

\section{Habitat and distribution}

UMMZ 203679-87 were collected at 0930-1045 h, at $0.3-3.0 \mathrm{~m}$ height, on tree trunks and branches, in a highly disturbed Euphorbia forest on sand dunes surrounded by active and abandoned sandy fields, $1 \mathrm{~km}$ from the seashore. 
The holotype is reported to have been collected at the southern tip of Madagascar, which is most likely between Tanjon' i Vohimena (Cap Ste. Marie) and Betanty (Faux-Cap). The UMMZ specimens were collected from near Betanty. Boettger (1913) assigned three males collected at Tsimanampetso (Lake Tsimanampetsotsa, $24^{\circ} 06^{\prime} \mathrm{S}, 43^{\circ} 40^{\prime} \mathrm{E}$ ) to $P$. breviceps, as well as a specimen from Fort Dauphin held at the Lübeck Museum. Loveridge (1942) and Angel (1942) also listed another locality, Andranovaho, although they do not refer to specific specimens. Because of the previous confusion with $P$. mutabilis, we are uncertain of the reliability of these other localities.

Phelsuma breviceps is probably restricted to the dry littoral forests of southern Madagascar. This type of habitat occurs on sandy substrate near the coast, and has been largely cleared for cultivation of corn, sweet potatoes, and peanuts in the Tanjon' i Vohimena and Betanty region. Two other Phelsuma species also occur in this region: $P$. modesta and $P$. lineata, but are largely restricted to introduced plants forming fence rows around fields.

\section{Remarks}

Boettger (1894) noted that the skin of the holotype (the only specimen available to him) was torn in several places, but he did not relate this to skin fragility in this species, probably because he never saw live individuals. Field observations of the new specimens from Betanty revealed extreme skin fragility in this species. All of the individuals caught by hand lost part or nearly all of their skin by struggling to free themselves. It proved impossible to hold these geckos in the hand, no matter how gently, without them suffering severe skin loss. The specimen photographed (Fig. 1) was captured by painstakingly chasing it along a branch into a plastic sack. Even though this individual was not touched, it suffered some skin damage (visible in the photograph) in the air filled plastic sack while being carefully transported a short distance to camp.

\section{Phelsuma masohoala sp. nov.}

(Figure 3)

Holotype. UMMZ 203688, mature female, collected 3 January 1993, at Cap Est, $1^{\circ} 15^{\prime} \mathrm{S}, 50^{\circ} 29^{\prime} \mathrm{E}, 5 \mathrm{~m}$ altitude, Antalaha Fivondronana, Antsiranana Province, Madagascar, by Christopher J. Raxworthy.

Paratypes. None.

Diagnosis. A presumably medium-sized Phelsuma, $47 \mathrm{~mm}$ SVL; nostril placed directly above the suture between the rostral and first supralabial; median cleft on the rostral; one intersupranasal granule; chin with two dark chevrons; head and neck without a median line; head and body without green, blue, or red pigmentation.

Nine species of Phelsuma may have the nostril placed directly above the suture between the rostral and first supralabial; they differ from $P$. masohoala as follows: $P$. antanosy lacks a median cleft in the rostral, has keeled ventral scales, and has green and red pigmentation; $P$. cepediana and $P$. borbonica have $2-3$ intersupranasal granules, lack dark chevrons on the chin, and have green and red pigmentation; $P$. edwardnewtoni has three intersupranasal granules and reaches a SVL of $108 \mathrm{~mm}$; P. gigas has three intersupranasal granules and reaches a SVL of $190 \mathrm{~mm} ; P$. guentheri has 11-14 supralabials, 9-10 infralabials, and 


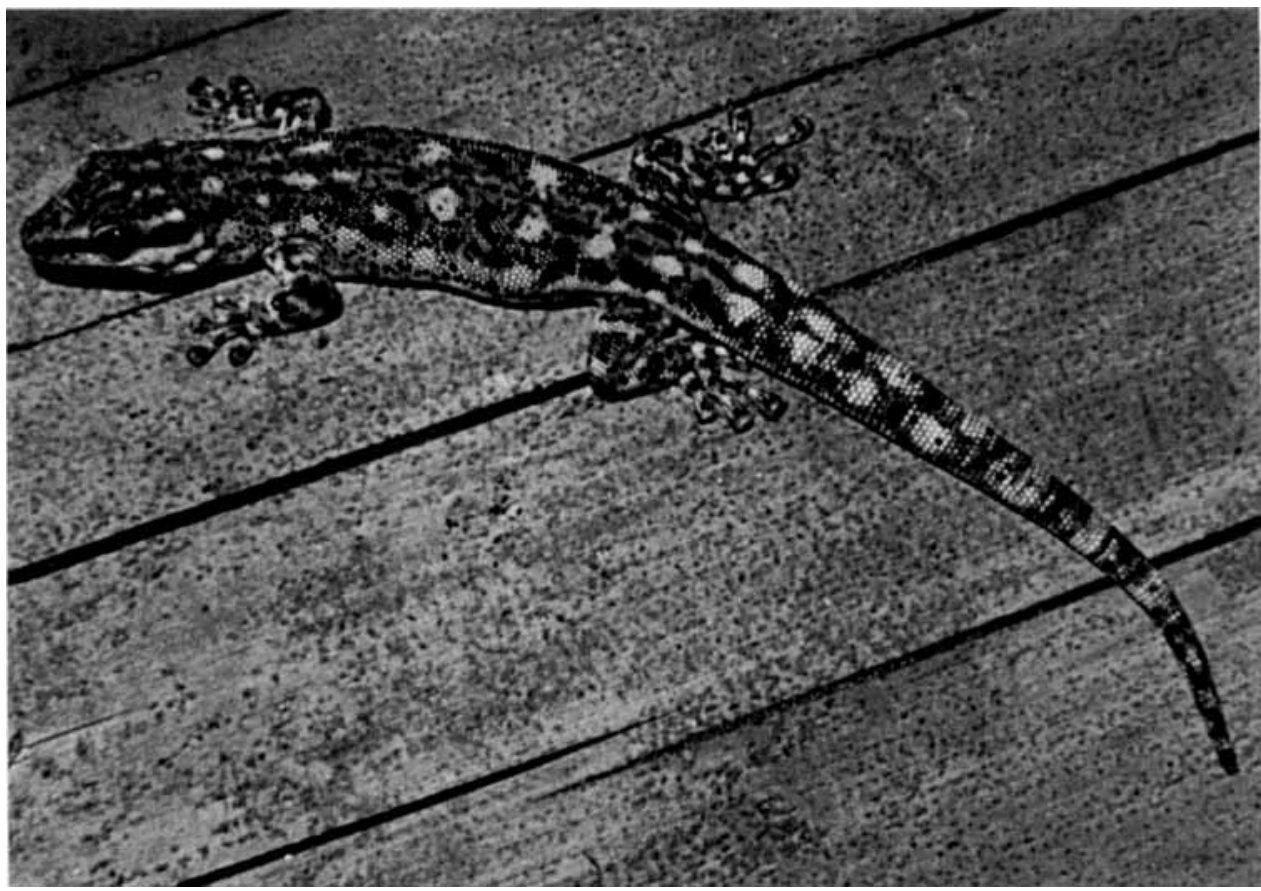

Figure 3. Holotype of Phelsuma masohoala sp. nov. (UMMZ 203688).

reaches a SVL of $125 \mathrm{~mm}$; $P$. guimbeaui has a median line on the head and neck and has green and red pigmentation; $P$. omata has slightly keeled dorsal scales and green or blue pigmentation; $P$. quadriocellata has keeled ventral scales and green pigmentation.

Phelsuma gigas and $P$. edwardnewtoni are now considered extinct (Vinson \& Vinson, 1969). Only two of the above species, Phelsuma cepediana and P. antanosy, occur in Madagascar.

\section{Description}

The specimen is well fixed and undamaged. The left oviduct contains three eggs, the largest $3 \mathrm{~mm}$ diameter, others $1 \mathrm{~mm}$ in diameter. Measurements: SVL $47 \mathrm{~mm}$; tail $52 \mathrm{~mm}$ (not regenerated); maximum body diameter $13 \mathrm{~mm}$; axilla-groin distance $23 \mathrm{~mm}$; forelimb length $15 \mathrm{~mm}$; hindlimb length $20 \mathrm{~mm}$; tympanum height $1 \mathrm{~mm}$. The nostril contacts the rostral, first supralabial, supranasal, and two postnasals; centre of nostril positioned above the suture between rostral and first supralabial; rostral with median suture (cleft); one intersupranasal granule; eight supralabials; seven infralabials; two large postmentals contact mental posteriorly; three distinct pairs of postmentals internal to the infralabials; scales posterior to postmentals gradually decrease in size posteriorly, forming small granules; snout 1.4 times as long as distance between eye and tympanum; smooth ventral scales on venter; smooth dorsal granules on body; subcaudals enlarged transversally, up to two times wider than long; tail whorls not present; tail profile smooth; forelimb with five digits, the internal (digit I) reduced in size; hindlimb with five digits, the internal (digit I) reduced 
in size; total number of subdigital scansors and median scales in order from digit I-V: right manus 5-13-14-16-13, left manus 5-12-14-17-12, right pes 4-12-17-21--14, left pes 4-12-16-21-15; pupil round.

The coloration in life is white dorsally with irregularly arranged fine black spots on the head, body, limbs and tail. On the body, there is a broken, diffuse-edged, black, dorsolateral line starting at shoulder and terminating at tail base, and a broken, diffuse-edged, black, lateral line starting posterior to forelimbs and terminating anterior to hindlimbs. A pale, yellow, vertebral line starts at the shoulders and fades on the anterior half of the tail. A broad, black, eye line starts at the nostril, passes through the eye, above the tympanum, and fades on the neck. The labials are white. Chin, throat, venter and ventral surfaces of limbs white and unspotted. The chin has two partly broken, thin, brown chevrons that point forward. The tail laterally has a longitudinal line of white spots bordered by fine black spots along its entire length. Ventrally the tail is white with diffuse greyish-brown spots that are most dense at the tail tip. Iris reddish-brown.

After 3 months in formalin and 3 months in alcohol, the yellow pigment has become grey. The black markings have faded to dark grey.

\section{Etymology}

The name 'masohoala' is the local name of the coast and peninsula where the holotype was collected, and refers to the boat-passages in the reef that must be examined carefully by eye. The peninsular name 'Masoala' that has been used on maps since the last century probably originated as a cartographic error.

\section{Habitat and distribution}

UMMZ 203688 was collected at $0900 \mathrm{~h}$, at $0.3 \mathrm{~m}$ height, on a tree trunk $(0.2 \mathrm{~m}$ diameter $)$, in partly degraded littoral forest, $30 \mathrm{~m}$ from the shore. The littoral forest was on a sandy substrate.

No other specimens were found despite intensive searches made in the same and other areas of littoral forest around Cap Est. These forests also have populations of $P$. guttata, $P$. laticauda, $P$. madagascariensis, $P$. pusilla and $P$. quadriocellata.

Phelsuma masohoala is probably endemic to the littoral forests of the eastern side of the Masoala Peninsula. The littoral forest is restricted to sandy substrate close to the coast, and has been largely cleared for vanilla and palm oil plantations in the Antalaha-Ambohitralanana region. The extreme rarity of $P$. masohoala compared to the other sympatric Phelsuma species makes us think this species may normally occupy the upper canopy of littoral forest, and therefore is easily overlooked.

\section{Remarks}

The position of the nostril in $P$. masohoala directly above the suture between the first supralabial and the rostral, is unknown for any other endemic Malagasy species except $P$. antanosy (Raxworthy \& Nussbaum, 1993) and P. quadriocellata (Rösler, 1987). Phelsuma cepediana, a non-endemic species possibly accidentally introduced to Madagascar from Mauritius, also has the nostril positioned above 
the suture. All other Malagasy species have the nostril posterior to the suture between the rostral and first supralabial.

The coloration of $P$. masohoala is unusual in that it lacks green pigment, a characteristic shared within Madagascar by $P$. mutabilis, $P$. breviceps, $P$. dubia and $P$. modesta, all of which live on tree trunks in dry deciduous forests. The sympatric Phelsuma species found in littoral forest with $P$. masohoala were all predominantly green, and were frequently found in Pandanus screw palms and on palm fronds. The drab coloration of $P$. masohoala suggests it may be adapted to live on tree trunks.

\section{CHECKLIST OF PHELSUMA FROM MADAGASCAR}

A total of 20 Phelsuma species occur in Madagascar, 16 of which are endemic to the island. These are listed below, with the non-endemic species indicated with an asterisk.

Phelsuma Gray, 1825

Phelsuma abbotti* Stejneger, 1893

Phelsuma antanosy Raxworthy \& Nussbaum, 1993

Phelsuma barbouri Loveridge, 1942

Phelsuma breviceps Boettger, 1894

Phelsuma cepediana* (Merrem, 1820)

Phelsuma dubia* (Boettger, 1881)

Phelsuma flavigularis Mertens, 1962

Phelsuma guttata Kaudern, 1922

Phelsuma klemmeri Seipp, 1991

Phelsuma laticauda* (Boettger, 1880)

Phelsuma lineata Gray, 1842

Phelsuma madagascariensis Gray, 1831

Phelsuma modesta Mertens, 1970

Phelsuma masohoala sp. nov.

Phelsuma mutabilis (Grandidier, 1869)

Phelsuma pusilla Mertens, 1964

Phelsuma quadriocellata (Peters 1883)

Phelsuma seippi Meier, 1987

Phelsuma serraticauda, Mertens, 1963

Phelsuma standingi Methuen \& Hewitt, 1913

\section{IDENTIFICATION KEY TO THE PHELSUMA OF MADAGASCAR}

The tail characters are based on original tails. Regenerated sections will not show all diagnostic features of the tails. Regenerated tails can be readily identified by the distinct break line and change in scalation and colour pattern. 'In life' pigmentation characters will not usually be preserved in fixed specimens.

1a Subcaudals less than twice as wide as long 2

lb Subcaudals more than twice as wide as long 15

2a Ventrals of body keeled 3

$2 \mathrm{~b}$ Ventrals of body smooth 9

3a Obvious dark lateral line in body 4 
3b No dark lateral line on body

4a Tail with serrated tail whorls

5

P. pusilla

$P$. lineata

$P$. serraticauda

6

5b Tail without thin lateral fringe

6a Large black spot behind front limb insertion point

6b No large black spot behind front limb insertion point

7a Dorsolateral granules much larger than dorsal granules on body

$7 \mathrm{~b}$ Dorsolateral granules almost same size as dorsal granules on body

8 a Dorsal granules of tail base keeled

$8 \mathrm{~b}$ Dorsal granules of tail base smooth

9a Head and body strongly flattened dorsoventrally. Body with black lateral line. In life, head metallic yellow and body metallic blue

P. quadriocellata 7

P. flavigularis

8

P. antanosy

P. cepediana

P. klemmeri

10

P. standingi

11

P. dubia

12

P. masohoala

sp. nov.

P. barbouri

14

P. modesta grey, brown or blue, with or without red spots

$14 \mathrm{~b}$ Tail ventrally grey (in life pale green) and unspotted. Throat and body ventrally grey (in life pale green). In life body dorsally green with red spots.

P. cepediana

15a Chin and throat with 2-3 dark forward pointing chevrons

15b Chin and throat without 2-3 dark forward pointing chevrons

16a Dorsolateral granules of body much larger than dorsal granules

16b Dorsolateral granules of body almost same size as dorsal granules

\section{6}

18

P. abbotti 
17a Dorsal scales of tail base keeled. In life, tail underside pale orange

$17 \mathrm{~b}$ Dorsal scales of tail base smooth. In life, tail underside white

P. seippi

P. guttata

18a Dorsolateral body scales keeled. In life, body green or yellow, typically with some red spots

$18 \mathrm{~b}$ Dorsolateral body scales smooth. In life, body grey, without red spots

19a Dorsolateral granules much larger than dorsal granules of body. Adult SVL greater than $60 \mathrm{~mm}$

19b Dorsolateral granules almost same size as dorsal granules of body. Adult SVL less than $60 \mathrm{~mm}$

\section{P. madagascariensis}

P. laticauda

20a Chin with dark line on interior border of infralabials. Granules behind postmentals decrease gradually in size posteriorly. In life, skin not fragile

P. mutabilis

20b Chin without dark line on interior border of infralabials. Granules behind postmentals small and do not decrease in size posteriorly. In life, skin very fragile

P. breviceps

\section{DISCUSSION}

The vast majority of the Phelsuma that occur in Madagascar and all the Seychelles species have the nostril positioned above the first supralabial. Of the 15 Malagasy endemics, just $P$. masohoala, $P$. antanosy and $P$. quadriocellata are known to have the nostril above the rostral-supralabial suture, a character otherwise restricted to seven species found on Mauritius, Reunion, and Rodriguez islands and satellites to the east of Madagascar.

The relationships within the genus are unknown, but $P$. masohoala and $P$. antanosy may prove to be more closely related to Mascarene Island species than the other Madagascan species. If Phelsuma from Mauritius, Reunion or Rodriguez had dispersed to Madagascar by rafting they would most likely colonize coastal regions of Madagascar, especially on the eastern side of the island. The known localities for $P$. masohoala and $P$. antanosy are both in coastal forests in northeastern and southeastern Madagascar.

No other Phelsuma species has integument as fragile as that of $P$. breviceps. The degree of integument fragility in $P$. breviceps is similar to that of two other Malagasy geckos, Geckolepis maculata and G. typica, and Ailuronyx seychellensis of the Seychelles Islands.

The evolutionary significance of integumentary loss in geckos was recently discussed by Bauer \& Russell (1992). They suggested this trait evolved independently in several gecko lineages and is especially common among island species. Integumentary loss is considered to be a predator escape strategy that evolved in response to predators that use grasping or pinning during capture, such as primates and snakes. The predators of $P$. breviceps at Betanty are unknown, although in our experience dry coastal forests may support many species of colubrid snake. At Betanty we recorded the following colubrid snakes: Dromicodryas bernieri (Duméril \& Bibron, 1854); Leioheterodon geayi Mocquard, 1905; Liophidium trilineatum Boulenger, 1896 and Mimophis mahfalensis (Grandidier, 1867). 
In southern Madagascar we found Phelsuma mutabilis in the stomachs of two colubrid snakes, Lycodryas guentheri (Boulenger, 1896) and Langaha nasutus Shaw, 1790.

We have seen integumentary tearing in three other Malagasy Phelsuma species: $P$. seippi, $P$. guttata and $P$. madagascariensis, although none of these species has the extreme fragility of $P$. breviceps. Integumentary loss is also reported for the Round Island species P. guentheri (Bauer \& Russell, 1992). The five Phelsuma species that exhibit integumentary loss occur in a wide range of habitats, from dry coastal vegetation to rainforest up to $1000 \mathrm{~m}$ altitude. There is no obvious explanation to suggest why this escape mechanism should be restricted to just these species.

The new species described in this paper, as well as the two most recently described species, $P$. klemmeri and $P$. antanosy, were all collected in natural coastal vegctation. Phelsuma antanosy and $P$. masohoala are specialists of littoral forest whereas $P$. klemmeri is a specialist of bamboo. All three species have small known distributions and are probably endemic to small coastal regions of Madagascar. The Malagasy coastal habitats are extremely diverse due to the large climatic variations found within Madagascar (Koechlin, 1972). Phelsuma has obviously colonized many coastal regions (perhaps partly by oceanic dispersal) and in some cases this has led to the evolution of locally endemic forms that are restricted to specific coastal habitats.

The protection of coastal habitats provides one of the greatest conservation challenges in Madagascar. The human pressures on the native coastal forests at both Masoala and Betanty are substantial. In both cases natural forest has been largely cleared for cultivation, and continued destruction of coastal habitats will likely lead to the extinction of both species. A similar problem has also been reported for $P$. antanosy with the vegetation at the type locality near Tôlanaro having been destroyed for timber, fuel, and agricultural land (Raxworthy \& Nussbaum, 1993).

The presence of locally endemic Phelsuma species suggests that other endemic species of plants and animals may occur in littoral forests and that the biogeographic importance of these coastal forests has not been fully appreciated. Coastal habitats must have once included a significant fraction of Madagascar's biodiversity although they have now been largely cleared for agriculture. More intensive surveys of surviving coastal habitats are needed to assess their importance in relation to other, better-known forest types.

\section{ACKNOWLEDGEMENTS}

We thank Angelin and Angeluc Razafimanantsoa for their enthusiasm and help during the Masoala survey, George and Magali Van Schalkwyk for considerable assistance at Cap Est, and Gabriellà Raharimanana, Roberson Ialy, and Miha Gerald for help in surveying near Betanty. We also wish to acknowledge the Ministère de l'Enseignement Supérieur, the Ministère de la Production Animale et des Eaux et Forêts and the Ministère de la Recherche Scientifique et Technologie pour le Developpement whose cooperation made this research programme possible, and WWF for logistic support. We also thank D. Bay for assistance in illustrating this paper. This research was supported in part by CARE and NSF grant DEB-90-24505. 


\section{REFERENCES}

Angel F. 1942. Les lézards de Madagascar. Memoires de l'Acadamie Malgache 36: 1-193.

Bauer AM, Russell AP. 1992. The evolutionary significance of regional integumentary loss in island geckos: a complement to caudal autotomy. Ethology Ecology and Evolution 4: 343-358.

Blanc CP. 1972. Les Reptiles de Madagascar et des Iles Voisines. In: Battistini R, Richard-Vindard G, eds. Biogeography and Ecology in Madagascar. The Hague: W. Junk, 501-614.

Boettger O. 1894. Diagnosen eines Geckos und eines Chamaeleons aus Sud-Madagascar. Zoologischer Anzeiger 17: $137-140$

Boettger O. 1913. Reptilien und Amphibien von Madagascar, den Inseln und dem Festland Ostafrikas. (Sammlung Voeltzkow 1889-1895 und 1903-1905.) Dritter Band. Systematische Arbeiten 3: 269-374.

Börner R. 1972. Revision der Geckonidengattung Phelsuma Gray 1825. Miscellaneous Articles in Saurology 1: $1-145$.

Börner R. 1980. A new species of the Phelsuma lineata Group. Miscellaneous Ariicles in Saurology 6: 1-19.

Börner R, Minuth W. 1982. Advance diagnoses of new taxa of the Phelsuma madagascariensis group. Miscellaneous Articles in Saurology 11: 1-7.

Börner R, Minuth W. 1984. On the taxonomy of the Indian Ocean I.jzards of the Phelsuma madagascariensis species group (Reptilia, Geckonidae). Joumal of the Bombay Natural History Society 81: 242 281.

Gheke AS. 1981. Phelsuma Gray 1825 in the Seychelles and neighboring islands: a re-appraisal of their taxonomy and description of two new forms. Senckenbergiana Biologica 62: 181 198.

Grandidier A. 1869. Description de quelques animaux nouveaux découverts pendant l'année 1869 sur la côte Ouest de Madagascar. Revue et Magasin de Zoologie 21: 339-342.

Gray JE. 1825. A synopsis of the species of the class Reptilia. In Griffith E, Pidgeon E. eds. The Animal Kingdom Arranged in Conformity with its Organization by the Baron Curier. Vol. 9. London: Whittaker, Treacher and $\mathrm{Co}, 1-110$.

IUCN/UNEP/WWF 1987. Madagascar, an environmental profile. Cambridge: IUCN.

Koechlin J. 1972. Flora and vegetation of Madagascar. In: Battistini R, Richard-Vindard G, eds. Biogeography and Ecology in Madagascar. The Hague: W. Junk, 145-190.

Kluge AR. 1991. Checklist of gekkonidae lizards. Smithsonian Herpetological Information Senvice 85: 1-35.

Loveridge AR. 1942. Revision of the Afro-Oriental geckos of the genus Phelsuma. Bulletin of the Museum of Comparative Zoology 89: 438-481.

Mertens R. 1962. Die Arten und Unterarten der Geckonengattung Phelsuma. Senckenbergiana Biologica 43: 81-127.

Mocquard F. 1901. Note préliminaire sur une collection de Reptiles et de Batraciens recueillis par $M$. Alluaud dans le sud de Madagascar. Bulletin du Muséum d'Histoire Naturelle. Paris 6: 251-256.

Mocquard F. 1902. Sur une collection de Reptiles et de Batraciens recueillis par M. Alluaud dans le sud de Madagascar. Bulletin de la Societé Philomathique de Paris. 9 sér. 4: 5--25.

Raxworthy CJ, Nussbaum RA. 1993. A new madagascan Phelsuma, with a review of Phelsuma trilineata and comments on Phelsuma cepediana in Madagascar (Squamata: Gekkonidae). Herpetologica 49: 342-349.

Rösler H. 1987. Mitteilung über eine Anomalie des Rostralschildes sowie zur Lage der Nasenöfnung bei Phelsuma quadriocellata quadriocellata (Peters, 1883) (Reptilia, Sauria, Gekkonidae). Zoologische Abhandlungen Staatliches Museum fur Tierkunde Dresden 42: 137-142.

Seipp R. 1991. Eine neue Art der Gattung Phelsuma Gray 1825 von Madagaskar (Reptilia: Sauria: Gekkonidae). Senckenbergiana Biologica 71: 11-14.

Vinson J, Vinson JM. 1969. The saurian fauna of the Mascarene Islands. The Mauritius Institute Bulletin 6: $203-320$.

Wermuth H. 1965. Liste der rezenten Amphibien und Reptilien Gekkonidae, Pygopodidae, Xantusiidae. Das Tierreich 80: 1-246. 